evidence that IUDs or a high dose of oestrogens taken post-coitally decrease endometrial carbonic anhydrase, and subsequently prevent uterine implantation.

\section{Conclusion}

Ovarian ectopic gestation is relatively rare and usually difficult to recognize before laparotomy. It is almost always ruptured at the time of exploration. The increasing reported incidence of ovarian pregnancy has a close relationship to the increased usage of IUDs and also to the greater awareness of physicians to this type of ectopic pregnancy. Specifically, more haemorrhagic ovaries are being subjected to wedge resection or total removal and careful sectioning for detection of ovarian pregnancy.

\section{Acknowledgments}

I would like to thank Dr Henry Puro and Dr Hushang Payan for their advice, and Miss Barbara James for her technical assistance.

\section{References}

Boronow, R.C., McElin, T.W., West, R.H. \& BuckingHAM, J.C. (1965) Ovarian pregnancy (report of four cases and a thirteen-year survey of the English literature). American Journal of Obstetrics and Gynecology, 91, 1095.

Campbell, J.S., Hacquebard, D.M., Mitton, D.M., Hurteau, G.D., Bobra, S.T. \& Sirois, J. (1974) Acute hemoperitoneum, IUD, and occult ovarian pregnancy. Obstetrics and Gynecology, 43, 438.

Craig, J.M. (1975) The pathology of birth control. Archives of Pathology, 99, 233.

Gérin-LAJoIE, L. (1951) Ovarian pregnancy. American Journal of Obstetrics and Gynecology, 62, 920.

IsBelL, N.P. \& BACON, W.B. (1947) Primary ovarian pregnancy. American Journal of Obstetrics and Gynecology, 54, 329.

Lehfeldt, H., Teitze, C. \& Gorstein, F. (1970) Ovarian pregnancy and the intrauterine device. American Journal of Obstetrics and Gynecology, 108, 1005.

MORRIS, J.M. \& VAN WAGENEN, G. (1973) Interception: the use of postovulatory estrogens to prevent implantation. American Journal of Obstetrics and Gynecology, 115, 101.

Pugh, W.E., Vogt, R.F. \& Gibson, R.A. (1973) Primary ovarian pregnancy and the intrauterine device. $O b$ stetrics and Gynecology, 42, 218.

SPEIGelberg, O. (1878) Zur Casuistik der Ovarialschwangerschaft. Archiv für Gynäkologie, 13, 73.

TIETZE, C. (1968) Correspondence. American Journal of Obstetrics and Gynecology, 101, 275.

Postgraduate Medical Journal (March 1977) 53, 155-156.

\title{
Septic abortion due to invasive Salmonella agona
}

\author{
A. P. BALl \\ B.Sc., M.B., Ch.B., M.R.C.P. (U.K.) \\ R. FOTHERGILL \\ M.B., Ch.B., M.R.C.S., L.R.C.P.
}

East Birmingham Hospital (Department of Communicable and Tropical Diseases), Birmingham B9 5ST

SEPTIC abortion is rarely associated with organisms other than clostridia, staphylococci, streptococci and anaerobes which are introduced into the uterus. Septic abortion occurring as a complication of an invading blood-borne pathogen is extremely uncommon. The present patient is interesting in that Salmonella agona, which until 1970 was an unusual serotype (Leading Article, 1971), was the cause of a septic abortion due to intrauterine infection consequent on a septicaemic illness.

\section{Case report}

The patient, a previously healthy 28-year-old primigravid housewife, who was 14 weeks pregnant,

Correspondence: Dr A. P. Ball, Department of Communicable and Tropical Diseases, Bordesley Green East, East Birmingham Hospital, Birmingham B9 5ST. was admitted to hospital with a 2-day history of malaise, fever and lower abdominal pain followed $24 \mathrm{hr}$ later by rigors and vaginal bleeding containing products of conception. On admission, she was flushed and sweating with a pyrexia of $39 \cdot 4^{\circ} \mathrm{C}$, a tachycardia of 100 and a blood pressure of $120 / 70$ $\mathrm{mmHg}$. The abdomen was distended and there was guarding and tenderness in both iliac fossae. Vaginal examination revealed fresh blood appearing from a soft, one-finger dilated cervix and bimanual examination elicited marked tenderness of the uterus and the lateral fornices. A diagnosis of incomplete septic abortion was made and the patient received ampicillin $500 \mathrm{mg}$ i.m. followed by amoxycillin 500 $\mathrm{mg} / 8 \mathrm{hr}$ thereafter. The vaginal bleeding continued and another vaginal examination revealed a furtherdilated cervix with placental remnants protruding. 
Attempts to remove these with sponge forceps were unsuccessful and on day 3 of admission uterine evacuation and curettage was performed.

Haemoglobin was $11.2 \mathrm{~g} / \mathrm{dl}$; WCC 6700; ESR 86 . Initial blood cultures were negative but $S$. agona was grown from a mid-stream urine specimen, high vaginal swab and from the curettings. The organism was sensitive to ampicillin, sulphonamides, cotrimoxazole, nalidixic acid and nitrofurantoin.

Following operation, the patient, for the first and only time, developed mild diarrhoea lasting $24 \mathrm{hr}$. Stool cultures were positive for $S$. agona and the Widal reaction was positive, TO $1 / 1600$ BO $1 / 125$, a cross reaction compatible with $S$. agona. Amoxycillin was continued for 7 days, the pyrexia having remitted by day 2 of admission. Subsequent stool cultures remained positive and the patient was discharged well after 10 days.

\section{Discussion}

This patient suffered an illness suggestive of septicaemia during which septic abortion occurred. Salmonella agona was isolated from the uterine curettings and conceptus and, although the blood culture was negative, the positive Widal reaction provides further evidence of an invasive $S$. agona infection with subsequent invasion of the uterine contents. Isolation of the organism from the urine might also indicate an invasive illness although the possibility of vulval contamination of the specimen by $S$. agona was high. The absence of leucocytosis is in keeping with an invasive salmonellosis. Patients with salmonellosis due to non-enteric organisms, may suffer a 'septicaemic' or 'typhoidal' illness (Christie, 1974) and this patient, having none of the typhoidal features (splenomegaly, rose spots), is considered to have been a septicaemic case.
No previous report of $S$. agona causing septis abortion could be found in the literature and repor of septic abortion consequent on salmonellosis are rare (Vorburger et al., 1974). Saphra and Wassermap. (1954), in a review of 329 infections with $S$. cholera suis, found four cases of whom two had organism recovered from the uterus, but could add no furtheㄹ. cases in an extended study of 7779 infections wit all Salmonella spp. excluding $S$. typhi (Saphra an\& Winter, 1957). Huckstep (1962) recalls two cases off miscarriage in association with typhoid fever, but does not state whether these cases were a true septic complication or purely an intercurrent phenomenon $\vec{t}$ The phenomenon is, therefore, rare but the possib? lity of its occurrence should be borne in mind in ans pregnant woman in whom bacteraemia is suspecte in the course of a gastroenteritic illness.

Salmonella infections are common and are usuallis considered trivial. This report indicates their poten-v tial to produce severe life-threatening disease.

\section{References}

Christie, A.B. (1974) Infectious Diseases: Epidemiology and Clinical Practice, 2nd Edn, p. 39. Churchill-Livingstone Edinburgh and London.

HuCKSTEP, R.L. (1962) Typhoid Fever and Other Salmonella. Infections, p. 172. E. \& S. Livingstone, Ltd. Edinburgh \&n London.

LEADING ARTICLE (1971) Salmonella agona infection British Medical Journal, 2, 347.

Saphra, I. \& WassermanN, M. (1954) A clinical and e⿱乛龰pis demiological evaluation of 329 infections identified be tween 1940 and 1954 in the New York Salmonella Centera American Journal of Medical Science, 288, 525.

SAPHRA, I. \& Winter, J.W. (1957) Clinical manifestations of salmonellosis in man. New England Journal of Medicine $\overrightarrow{\bar{S}}$ 256, 1128.

Vorburger, J., Stamm, O., Pagon, S. \& Schmidt, E. (1974? Salmonella indiana als mögliche Ursache einer Fehlgeburt? Geburtshilfe und Frauenheilkunde, 34, 573. 